\title{
Dentists' level of knowledge of the treatment plans for periodontal ligament injuries after dentoalveolar trauma
}

\section{Denise Pedrini(a) \\ Sônia Regina Panzarini(a) \\ Wilson Roberto Poi ${ }^{(a)}$ \\ Maria Lúcia Marçal Mazza \\ Sundefeld ${ }^{(b)}$ \\ Adelisa Rodolfo Ferreira Tiveron ${ }^{(c)}$}

(a) Department of Surgery and Integrated Clinic, School of Dentistry of Araçatuba, UNESP - Univ Estadual Paulista, Araçatuba, SP, Brazil.

(b) Department of Pediatric and Community Dentistry, School of Dentistry of Araçatuba, UNESP - Univ Estadual Paulista, Araçatuba, SP, Brazil.

(c) Postgraduate Program in Pediatric Dentistry, School of Dentistry of Araçatuba, UNESP - Univ Estadual Paulista, Araçatuba, SP, Brazil.
Declaration of Interests: The authors certify that they have no commercial or associative interest that represents a conflict of interest in connection with the manuscript.

Corresponding author:

Denise Pedrini

Email: pedrini@foa.unesp.br

Received for publication on Feb 04, 2011 Accepted for publication on May 27, 2011

\begin{abstract}
This study investigated the level of knowledge held by dentists about the possible treatment plan procedures for periodontal ligament injuries after dentoalveolar trauma. A 5-item self-applied questionnaire was prepared with questions referring to the professional profile of the interviewees and to the treatment plan they would propose for periodontal ligament injuries secondary to dentoalveolar trauma. The questionnaires were filled out by 693 dentists attending the $23^{\text {rd }}$ Annual Meeting of the Brazilian Society for Dental Research, and the data obtained were subjected to descriptive analysis. Either the chi-square test or Fisher's exact test was applied to assess associations among variables, at a 5\% level of significance. The results revealed that dentists experienced difficulty in establishing a treatment plan for subluxation, and for extrusive, lateral and intrusive luxations. In general, holding a dental specialty degree had no influence on the knowledge about treatment plan procedures for the most severe injuries. It could be concluded that the dentists participating in this study, whether specialists or not, did not have sufficient knowledge to treat most of the periodontal ligament injuries resulting from dentoalveolar trauma adequately.
\end{abstract}

Descriptors: Tooth Injuries; Patient Care Planning; Periodontal Ligament.

\section{Introduction}

The nature and complexity of dentoalveolar traumas vary considerably. In most cases, immediate and proper treatment can minimize the emotional distress experienced by patients and improve case prognosis. ${ }^{1}$ However, dentists must be familiar with the different types of injuries involving teeth and supporting tissues, and must know how to handle trauma cases, from emergency care to the most suitable clinical protocol for each type of injury. An ill-advised first treatment may have esthetic and functional implications that will worsen the discomfort and cause greater inconveniences to the patient, possibly even increasing treatment costs if more complex procedures are required. ${ }^{2}$ The chances of complications arising from traumatized teeth, such as pulp necrosis, external root resorption and even tooth loss, increase significantly if adequate immediate treatment and long-term follow-up is not given. ${ }^{3}$ 
The World Health Organization developed a classification for dental trauma that includes teeth, supporting tissues, gingiva and oral mucosa. This classification may be applied to both primary and permanent dentitions. ${ }^{4}$ Dentoalveolar traumas involving tooth supporting structures usually present concomitant pulpal and periodontal injuries, requiring an interdisciplinary approach, which is characteristic of the training given to general dentists. ${ }^{5}$

The frequency of dentoalveolar trauma cases tends to increase owing to an increasing involvement of young patients, ${ }^{6,7}$ thus posing a public health challenge. The purpose of this study was to evaluate the level of knowledge held by dentists regarding the treatment of periodontal ligament injuries resulting from dentoalveolar trauma.

\section{Methodology}

The research protocol for this study was reviewed and approved by the local Research Ethics Committee.

A 5-item self-applied questionnaire was developed for the study (Figure 1). The questions referred to the professional profile of the interviewees and the treatment plan they would propose for the management of periodontal ligament injuries resulting from dentoalveloar trauma, except for avulsion. The classification ${ }^{4}$ devised by Andreasen, based on the classification proposed by the World Health Organization (1969), was used to group the periodontal ligament injuries evaluated by the participants. The respondents were required to devise treatment plans for these periodontal ligament injuries by selecting answers from a list of 11 multiple-choice items, according to their own judgment. The treatment plan procedures proposed by the participants were classified as adequate or inadequate, based on researchbased data published in international literature $e^{4,8}$ (Table 1).

The questionnaires were handed out to dentists attending the $23^{\text {rd }}$ Annual Meeting of the Brazilian Society for Dental Research. The participants were asked to complete the questionnaires with no interference from the interviewer. All participants were volunteers and their identity was kept confidential. Three authors reviewed each questionnaire. There was no disagreement between examiners.

The data were subjected to statistical analysis using Epi-info 3.4.1. software (Centers for Disease Control and Prevention, Atlanta, USA). The descriptive statistics included an analysis of the frequency distribution of responses to the questions posed to the participants. Associations among the variables were assessed with the chi-square or Fisher's Exact tests at a 5\% significance level $(\mathrm{p}=0.05)$.

\section{Results}

The questionnaires were handed out to 693 of the 3,675 dentists attending the Meeting. Four hundred and eighty one $(69.4 \%)$ participants had graduated 0 to 9 years prior, 162 (23.4\%), 10 to 19 years prior, and $50(7.2 \%), 20$ to 42 years prior. As to age, $419(60.4 \%)$ of the participants were 21 to 30 years old, $198(28.6 \%)$ were 31 to 40 years old and 73 $(10.6 \%)$ were 41 to 65 years old. Three $(0.4 \%)$ participants did not answer this question.

Four hundred and ninety seven $(71.7 \%)$ participants held a specialist degree, $187(27 \%)$ were general dentists and $9(1.3 \%)$ did not answer this question. The areas of expertise of the specialists were distributed as follows: Pediatric Dentistry $(\mathrm{n}=104$; $20 \%)$, Endodontics ( $\mathrm{n}=87 ; 16.8 \%)$, Prosthodontics $(\mathrm{n}=54 ; 10.4 \%)$; Restorative Dentistry $(\mathrm{n}=53$; $10.2 \%)$, Periodontics ( $\mathrm{n}=46 ; 8.9 \%$ ), Orthodontics $(\mathrm{n}=46 ; 8.9 \%)$, Public Health $(\mathrm{n}=33 ; 6.3 \%)$, Den-

Table 1 - Treatment plan procedures considered adequate for periodontal ligament injuries.

\begin{tabular}{|c|c|c|c|c|c|}
\hline \multirow{2}{*}{ Treatment plan } & \multicolumn{5}{|c|}{ Type of injury } \\
\hline & C & S & EL & $\mathrm{LL}$ & IL \\
\hline Radiographic exam & $x$ & $x$ & $x$ & $x$ & $x$ \\
\hline Tooth repositioning & & & $x$ & $x$ & $x$ \\
\hline $\begin{array}{l}\text { Surgical extrusion or orthodontic extrusion or } \\
\text { watchful waiting for spontaneous re-eruption }\end{array}$ & & & & & $x$ \\
\hline Splinting & & $x$ & $x$ & $x$ & $x$ \\
\hline Occlusal adjustment & & & $x$ & $x$ & $x$ \\
\hline Antibiotic therapy & & & $x$ & $x$ & $x$ \\
\hline Endodontic treatment & & & $x$ & $x$ & $x$ \\
\hline Follow-up & $x$ & $x$ & $x$ & $x$ & $x$ \\
\hline
\end{tabular}




\begin{tabular}{|c|c|c|c|}
\hline \multicolumn{4}{|c|}{ QUESTIONNAIRE } \\
\hline \multicolumn{4}{|c|}{ 1. Please state the year you graduated from dental school } \\
\hline \multicolumn{4}{|c|}{ 2. Please state your age } \\
\hline \multicolumn{3}{|c|}{ 3. Specialization course? Yes ( ) No ( ) Specify: } & Year of conclusion: \\
\hline \multicolumn{4}{|c|}{$\begin{array}{l}\text { 4. For the purpose of facilitating the treatment of periodontal ligament injuries, a classification was proposed by Andreasen based on the } \\
\text { classification proposed by the World Health Organization (1969). Considering this classification, presented in the table below, please mark } \\
\text { which procedure(s) you would indicate as part of a treatment plan for each type of dental trauma. (YOU CAN CHOOSE ONE OR MORE } \\
\text { OPTIONS FOR EACH TYPE OF INJURY). }\end{array}$} \\
\hline Schematic & Type of injury & \multicolumn{2}{|c|}{ Treatment plan } \\
\hline$\frac{8}{3}$ & $\begin{array}{c}\text { Concussion } \\
\text { (C) }\end{array}$ & $\begin{array}{l}\text { 1. ( ) Radiographic exam } \\
\text { 2. ( ) Tooth repositioning } \\
\text { 3. ( ) Surgical extrusion } \\
\text { 4. ( ) Orthodontic extrusion } \\
\text { 5. ( ) Watchful waiting for spontaneous re-eruption } \\
\text { 6. ( ) Splinting } \\
\text { Splinting time: }\end{array}$ & $\begin{array}{l}\text { 7. ( ) Occlusal adjustment } \\
\text { 8. ( ) Antibiotic therapy } \\
\text { 9. ( ) Endodontic treatment } \\
\text { 10. ( ) Follow-up } \\
\text { 11. ( ) Other - specify: }\end{array}$ \\
\hline (3) & $\begin{array}{l}\text { Subluxation } \\
\text { (S) }\end{array}$ & $\begin{array}{l}\text { 1. ( ) Radiographic exam } \\
\text { 2. ( ) Tooth repositioning } \\
\text { 3. ( ) Surgical extrusion } \\
\text { 4. ( ) Orthodontic extrusion } \\
\text { 5. ( ) Watchful waiting for spontaneous re-eruption } \\
\text { 6. ( ) Splinting } \\
\text { Splinting time: }\end{array}$ & $\begin{array}{l}\text { 7. ( ) Occlusal adjustment } \\
\text { 8. ( ) Antibiotic therapy } \\
\text { 9. ( ) Endodontic treatment } \\
\text { 10. ( ) Follow-up } \\
\text { 11. ( ) Other - specify: }\end{array}$ \\
\hline 8 & $\begin{array}{l}\text { Extrusive Luxation } \\
\text { (EL) }\end{array}$ & $\begin{array}{l}\text { 1. ( ) Radiographic exam } \\
\text { 2. ( ) Tooth repositioning } \\
\text { 3. ( ) Surgical extrusion } \\
\text { 4. ( ) Orthodontic extrusion } \\
\text { 5. () Watchful waiting for spontaneous re-eruption } \\
\text { 6. () Splinting } \\
\text { Splinting time: }\end{array}$ & $\begin{array}{l}\text { 7. ( ) Occlusal adjustment } \\
\text { 8. ( ) Antibiotic therapy } \\
\text { 9. ( ) Endodontic treatment } \\
\text { 10. ( ) Follow-up } \\
\text { 11. ( ) Other - specify: }\end{array}$ \\
\hline$\sqrt[3]{3}$ & $\begin{array}{l}\text { Lateral Luxation } \\
\qquad(\mathrm{LL})\end{array}$ & $\begin{array}{l}\text { 1. ( ) Radiographic exam } \\
\text { 2. ( ) Tooth repositioning } \\
\text { 3. ( ) Surgical extrusion } \\
\text { 4. ( ) Orthodontic extrusion } \\
\text { 5. ( ) Watchful waiting for spontaneous re-eruption } \\
\text { 6. () Splinting } \\
\text { Splinting time: }\end{array}$ & $\begin{array}{l}\text { 7. ( ) Occlusal adjustment } \\
\text { 8. ( ) Antibiotic therapy } \\
\text { 9. ( ) Endodontic treatment } \\
\text { 10. ( ) Follow-up } \\
\text { 11. ( ) Other - specify: }\end{array}$ \\
\hline$\frac{3}{2}(\sqrt{1})$ & $\begin{array}{l}\text { Intrusive Luxation } \\
\text { (IL) }\end{array}$ & $\begin{array}{l}\text { 1. ( ) Radiographic exam } \\
\text { 2. ( ) Tooth repositioning } \\
\text { 3. ( ) Surgical extrusion } \\
\text { 4. ( ) Orthodontic extrusion } \\
\text { 5. ( ) Watchful waiting for spontaneous re-eruption } \\
\text { 6. ( ) Splinting } \\
\text { Splinting time: }\end{array}$ & $\begin{array}{l}\text { 7. ( ) Occlusal adjustment } \\
\text { 8. ( ) Antibiotic therapy } \\
\text { 9. ( ) Endodontic treatment } \\
\text { 10. ( ) Follow-up } \\
\text { 11. ( ) Other - specify: }\end{array}$ \\
\hline \multicolumn{4}{|c|}{$\begin{array}{l}\text { 5. Would you be able to treat all types of dental trauma presented in the table above? Yes ( ) No ( ) } \\
\text { Justify your answer: }\end{array}$} \\
\hline
\end{tabular}

Figure 1 - The self-applied questionnaire developed for the study.

tomaxillofacial Imaging $(\mathrm{n}=21 ; 4.0 \%)$, Oral and Maxillofacial Surgery and Traumatology $(\mathrm{n}=17$; $3.3 \%)$, Implantology ( $\mathrm{n}=17 ; 3.3 \%)$, Oral Diagnosis $(\mathrm{n}=12 ; 2.3 \%)$ and other areas $(\mathrm{n}=29 ; 5.6 \%)$. The sum of frequencies is greater than the number of specialized dentists because 22 participants $(4.4 \%)$ held more than one specialty degree.

As to the adequacy of the treatment plan pro- 
cedures proposed by the respondents, $502(72.4 \%)$ were adequate and $191(27.6 \%)$ were inadequate for concussion; $191(27.6 \%)$ were adequate and 502 $(72.4 \%)$ were inadequate for subluxation; $36(5.2 \%)$ were adequate and $657(94.8 \%)$ were inadequate for extrusive luxation; $88(12.7 \%)$ were adequate and $605(87.3 \%)$ were inadequate for lateral luxation; and, finally, $3(0.4 \%)$ were adequate and 690 $(99.6 \%)$ were inadequate for intrusive luxation.

The splinting times proposed by the participants for each type of injury are presented in Table 2.

The distribution of adequate and inadequate treatment plan procedures according to time since graduation is presented in Table 3. The result for intrusive luxation was not analyzed statistically, since only 3 dentists answered the item correctly.

A comparison between general dentists and specialists regarding proposed treatment plan procedures is presented in Table 4. The result for intrusive luxation was not analyzed statistically, since only 3

Table 2 - Splinting time proposed by the respondents for each type of tooth injury.

\begin{tabular}{|c|c|c|c|c|c|}
\hline $\begin{array}{c}\text { Time } \\
\text { (weeks) }\end{array}$ & $\begin{array}{c}C \\
n(\%)\end{array}$ & $\begin{array}{c}\text { S } \\
\text { n (\%) }\end{array}$ & $\begin{array}{c}\text { EL } \\
n(\%)\end{array}$ & $\begin{array}{c}\mathrm{LL} \\
\mathrm{n}(\%)\end{array}$ & $\begin{array}{c}\text { IL } \\
\text { n (\%) }\end{array}$ \\
\hline 1 to 2 & $27 \quad(75.0)$ & $99 \quad(63.1)$ & $213 \quad(46.6)$ & $148 \quad$ (34.3) & $46 \quad(35.1)$ \\
\hline 2 to 3 & $1 \quad(2.8)$ & $9 \quad(5.7)$ & $56 \quad(12.3)$ & $50 \quad(11.5)$ & $14 \quad(10.7)$ \\
\hline 3 to 4 & $4 \quad(11.1)$ & $23 \quad(14.6)$ & $72 \quad(15.8)$ & $68 \quad(15.7)$ & $21 \quad(16.0)$ \\
\hline 5 to 48 & $4 \quad(11.1)$ & $24 \quad(15.3)$ & 113 (24.8) & 164 (38.0) & $50 \quad(38.2)$ \\
\hline Don't know & $\begin{array}{ll}0 & (0.0)\end{array}$ & $2 \quad(1.3)$ & $(0.5)$ & $(0.5)$ & $(0.0)$ \\
\hline Total ${ }^{*}$ & $36(100.0)$ & 157 (100.0) & 458 (100.0) & $432(100.0)$ & 131 (100.0) \\
\hline
\end{tabular}

$\mathrm{C}=$ concussion; $\mathrm{S}=$ subluxation; $\mathrm{EL}=$ extrusive luxation; $\mathrm{LL}=$ lateral luxation; $\mathrm{IL}=$ intrusive luxation. * The total of each column corresponds to the number of dentists that answered this question among the total 693 participants.

Table 3 - Distribution of adequate and inadequate treatment plan procedures proposed for concussion, subluxation, extrusive luxation and lateral luxation according to time since graduation $(n=693)$.

\begin{tabular}{|c|c|c|}
\hline \multirow{2}{*}{$\begin{array}{c}\text { Time since graduation } \\
\text { (years) }\end{array}$} & \multicolumn{2}{|c|}{ Concussion $\left(\chi^{2}=14.5051, p=0.0127\right)$} \\
\hline & Adequate $\mathrm{n}(\%)$ & Inadequate $\mathrm{n}(\%)$ \\
\hline 0 to 9 & $356.0(74.0)$ & $125.0(26.0)$ \\
\hline 10 to 19 & $118.0(72.8)$ & $44.0(27.2)$ \\
\hline 20 a 42 & $28.0(56.0)$ & $22.0(44.0)$ \\
\hline \multirow{2}{*}{$\begin{array}{c}\text { Time since graduation } \\
\text { (years) }\end{array}$} & \multicolumn{2}{|c|}{ Subluxation $\left(\chi^{2}=6.0730, p=0.2992\right)$} \\
\hline & Adequate $\mathrm{n}(\%)$ & Inadequate $\mathrm{n}(\%)$ \\
\hline 0 to 9 & $142.0(29.5)$ & $339.0(70.5)$ \\
\hline 10 to 19 & $40.0(24.7)$ & $122.0(75.3)$ \\
\hline 20 a 42 & $9.0(18.0)$ & $41.0(82.0)$ \\
\hline \multirow{2}{*}{$\begin{array}{c}\text { Time since graduation } \\
\text { (years) }\end{array}$} & \multicolumn{2}{|c|}{ Extrusive luxation (Fisher's Exact test, $p=0.8753$ ) } \\
\hline & Adequate $\mathrm{n}(\%)$ & Inadequate $\mathrm{n}(\%)$ \\
\hline 0 to 9 & $25.0(5.2)$ & $456.0(94.8)$ \\
\hline 10 to 19 & $9.0(5.6)$ & $153.0(94.4)$ \\
\hline 20 a 42 & $2.0(4.0)$ & $48.0(96.0)$ \\
\hline \multirow{2}{*}{$\begin{array}{c}\text { Time since graduation } \\
\text { (years) }\end{array}$} & \multicolumn{2}{|c|}{ Lateral luxation (Fisher's Exact test, $p=0.2366$ ) } \\
\hline & Adequate $n(\%)$ & Inadequate $\mathrm{n}(\%)$ \\
\hline 0 to 9 & $67.0(13.9)$ & $414.0(86.1)$ \\
\hline 10 to 19 & $16.0(9.9)$ & $146.0(90.1)$ \\
\hline 20 a 42 & $5.0(10.0)$ & $45.0(90.0)$ \\
\hline
\end{tabular}


Table 4 - Comparison between general dentists and specialists regarding the treatment plan procedures proposed for concussion, subluxation, extrusive luxation and lateral luxation $(\mathrm{n}=684)^{*}$.

\begin{tabular}{|c|c|c|}
\hline \multirow{2}{*}{ Training } & \multicolumn{2}{|c|}{ Concussion $\left(\chi^{2}=0.7821, p=0.3765\right)$} \\
\hline & Adequate n (\%) & Inadequate n (\%) \\
\hline Specialist & $365(73.4)$ & $132(26.6)$ \\
\hline General dentist & $131(70.1)$ & $56(29.9)$ \\
\hline \multirow{2}{*}{ Training } & \multicolumn{2}{|c|}{ Subluxation $\left(\chi^{2}=3.4047, p=0.0412\right)$} \\
\hline & Adequate n (\%) & Inadequate n (\%) \\
\hline Specialist & $127(25.6)$ & $370(74.4)$ \\
\hline General dentist & $61(32.6)$ & $126(67.4)$ \\
\hline \multirow{2}{*}{ Training } & \multicolumn{2}{|c|}{ Extrusive luxation $\left(\chi^{2}=0.1979, p=0.6564\right)$} \\
\hline & Adequate n (\%) & Inadequate n (\%) \\
\hline Specialist & $25 \quad(5.0)$ & $472(95.0)$ \\
\hline General dentist & $11 \quad(5.9)$ & $176(94.1)$ \\
\hline \multirow{2}{*}{ Training } & \multicolumn{2}{|c|}{ Lateral luxation $\left(\chi^{2}=4.1405, p=0.0419\right)$} \\
\hline & Adequate $\mathrm{n}(\%)$ & Inadequate n (\%) \\
\hline Specialist & $56(11.3)$ & $441(88.7)$ \\
\hline General dentist & $32(17.1)$ & $155(82.9)$ \\
\hline
\end{tabular}

*Of the total 693 participants, 9 did not answer the question regarding their training as either general dentists or specialists.

dentists answered the item correctly.

Among the specialties, Pediatric Dentistry, Endodontics and Oral and Maxillofacial Surgery were analyzed separately because the professionals practicing in these areas are more likely to receive referral patients that suffered dentoalveolar trauma. The results for intrusive luxation were not analyzed statistically, for the same reason mentioned earlier. Only for extrusive luxation was there a statistically significant association $(\mathrm{p}=0.0001)$ between pediatric dentists, endodontists and oral and maxillofacial surgeons, on one hand, and the proposal for adequate treatment plan procedures, on the other, meaning that specialists in these areas proposed more adequate treatment plan procedures for extrusive luxation than did specialists in the other areas. As for concussion, all specialists proposed a large number of adequate treatment plan procedures, whereas the number of adequate procedures proposed for subluxation was low for all specialties. As for extrusive and lateral luxations, oral and maxillofacial surgeons gave a larger number of correct answers.
Table 5 - Comparison between general dentists and specialists regarding their self-perceived ability to treat all types of dental trauma presented in the questionnaire $(n=631)^{*}$.

\begin{tabular}{c|c|c|}
\hline \multirow{2}{*}{$\begin{array}{c}\text { Ability to treat } \\
\text { dental trauma }\end{array}$} & \multicolumn{2}{|c}{ Training } \\
\cline { 2 - 3 } & Specialist n (\%) & General dentist n (\%) \\
\hline Yes & $255(55.8)$ & $86(49.4)$ \\
\hline No & $202(44.2)$ & $88(50.6)$ \\
\hline Total $^{*}$ & $457(100.0)$ & $174(100.0)$ \\
\hline
\end{tabular}

$\chi^{2}=2.0610$ and $p=0.1511 .{ }^{*}$ Of the total number of participants that declared themselves general dentists or specialists $(n=684), 53$ did not answer question \# 5 of the questionnaire, resulting in a total of 631 valid answers.

Regarding question 5 of the questionnaire, 345 $(49.8 \%)$ dentists considered themselves capable of treating all types of dental trauma, whereas 295 $(42.6 \%)$ believed that they would be unable to treat any dental trauma case properly. There was no statistically significant association between training (general dentist or specialist) and ability to treat all types of periodontal ligament injuries (Table 5).

\section{Discussion}

Some factors are determinant for the successful treatment of dentoalveolar trauma cases: time elapsed since the accident, type of splinting, presence of bacterial infection and pulp necrosis, correct indication of endodontic therapy according to the clinical situation, tooth development stage and associated bone fractures. ${ }^{9}$

The radiographic exam is of paramount importance to complement the diagnosis because it provides information about root formation stage, lesions affecting dental hard tissues (especially the root), periodontal ligament space and the alveolar bone. The results showed that, regardless of the type of injury, radiographic exam was one of the most frequently mentioned components of the treatment plan.

In cases of concussion, periodontal structures suffer only minor traumas, and tooth dislodgment does not occur. A great number of the respondents proposed adequate treatment plan procedures for concussion, confirming that the less complex the trauma, the easier it is to devise a treatment plan, the fewer the sequelae and the better the prognosis.

Diagnosis of the pulp condition and the decision 
to perform endodontic therapy must be based on an evaluation of clinical observations - such as crown darkening and type of response to sensitivity tests and on radiographic findings - such as disturbances in the root development of immature teeth. ${ }^{4}$ Regarding the indication for endodontic treatment, there is no difference among the several types of trauma, except for severely intruded teeth. ${ }^{10}$ In these cases, pulp revascularization is not expected and, regardless of the clinical observations, endodontic therapy must be performed 1 to 2 weeks after trauma in order to prevent the occurrence of inflammatory root resorption. ${ }^{4}$

Intrusive luxation was the periodontal ligament injury that prompted the least number of correct answers, mainly because the dentists did not include endodontic treatment in their treatment plans.

The data collected from the questionnaires showed that dentists had little knowledge regarding trauma case management, especially the most complex types that cause the most severe sequelae. These findings are consistent with those found in literature. ${ }^{11}$ In general, basic biological aspects are overlooked, since a great part of the treatment plan procedures for more complex periodontal ligament injuries proposed in this study were inadequate.

Different treatment approaches have been suggested for intrusive luxations, including watchful waiting for spontaneous re-eruption, as well as orthodontic and surgical repositioning. Watchful waiting has been considered the treatment of choice for immature teeth, ${ }^{12}$ and orthodontic repositioning during 2 to 3 weeks has been considered the treatment of choice for mature teeth. ${ }^{4}$

When a tooth has greater mobility or is repositioned after dislodgment, it should be splinted in order to provide comfort to the patient and improve the periodontal and/or pulp healing process. A period of 2 to 3 weeks is usually sufficient in case of trauma to the periodontal ligament. If the trauma to the periodontal ligament is associated with bone fracture, 3 to 4 weeks are recommended. ${ }^{4}$ The data collected from the questionnaires (Table 2 ) revealed that excessively long splinting times were proposed, demonstrating lack of knowledge of the profession- als concerning the importance of splinting during the healing process of dentoalveolar traumas.

Occlusal adjustment is another important procedure, insofar as premature contacts represent an additional trauma. ${ }^{13}$ This item was frequently missing in the treatment plans and its absence may contribute negatively to case prognosis.

Follow-up is an essential step for any type of dental trauma, because it is impossible to determine the exact extent of damage to a traumatized tooth and to its supporting tissue, or predict its future consequences. ${ }^{4}$ In the treatment plans proposed in this study, follow-up was one of the most cited items for all types of injury.

A trauma case is an urgent situation that demands prompt intervention by the dentist due to the need for immediate treatment. ${ }^{4}$ Therefore, identifying the type of injury and its extent is essential for devising an adequate plan and for subsequent treatment and follow-up.

Although the sample of this study was composed mostly of researchers, this fact did not influence the results, since similar studies conducted with clinicians have come to similar conclusions. ${ }^{11,14}$

The findings of the present study revealed that, in general, the level of knowledge of the dentists interviewed was low, notwithstanding the existence of clinical protocols in the literature that indicate the most adequate treatment approaches for each type of injury. ${ }^{8,15}$ There is a low incidence of dentoalveolar traumas in clinical practice and, as a result, there is little experience on this subject and a low level of knowledge, thus hindering consolidation of this knowledge. ${ }^{16}$ Therefore, periodical educational campaigns communicating research-based clinical protocols are essential to keep dentists updated on this important matter.

\section{Conclusion}

It may be concluded that the dentists participating in this study, whether specialists or not, did not have sufficient knowledge to treat most of the periodontal ligament injuries resulting from dentoalveolar trauma adequately. 


\section{References}

1. Vasconcellos LGO, Brentel AS, Vanderlei AD, Vasconcellos LMR, Valera MC, Araújo MAM. Knowledge of general dentists in the current guidelines for emergency treatment of avulsed teeth and dental trauma prevention. Dent Traumatol. 2009 Dec;25(6):578-83.

2. Andreasen FM, Andreasen JO. Treatment of traumatic dental injuries. Shift in strategy. Int J Technol Assess Health Care.1990;6(4):588-602.

3. Rossi M, Rossi A, Queiroz AM, Nelson Filho P. Management of a complex dentoalveolar trauma: a case report. Braz Dent J. 2009;20(3):259-62.

4. Andreasen FM, Andreasen JO. Textbook and color atlas of traumatic injuries to the teeth. 3rd ed. Copenhagen: Munksgaard; 1994. Luxation injuries; p.315-82.

5. Leroy RL, Aps JK, Raes FM, Martens LC, De Boever JA. A multidisciplinary treatment approach to a complicated maxillary dental trauma: a case report. Endod Dent Traumatol. 2000 Jun;16(3):138-42.

6. Emerich K, Kaczmarek J. First aid for dental trauma caused by sports activities: state of knowledge, treatment and prevention. Sports Med. 2010 May;40(5):361-6.

7. Carvalho ML, Moysés SJ, Bueno RE, Shimakura S, Moysés ST. A geographical population analysis of dental trauma in school-children aged 12 and 15 in the city of Curitiba-Brazil. BMC Health Serv Res. 2010 Jul;10:203.

8. Flores MT, Andreasen JO, Bakland LK, Feiglin B, Gutmann $\mathrm{JL}$, Oikarinen $\mathrm{K}$, et al. Guidelines for the evaluation and management of traumatic dental injuries. Dent Traumatol. 2001 Aug;17(4):145-8.
9. Hammarström L, Blomlöf L, Lindskog S. Dynamics of dentoalveolar ankylosis and associated root resorption. Endod Dent Traumatol. 1989 Aug;5(4):163-75.

10. Andreasen FM, Pedersen BV. Prognosis of luxated permanent teeth - the development of pulp necrosis. Endod Dent Traumatol. 1985 Dec;1(6):207-20.

11. Manfrin TM, Boaventura RS, Poi WR, Panzarini SR, Sonoda CK, Sundefeld MLMM. Analysis of procedures used in tooth avulsion by 100 dental surgeons. Dent Traumatol. 2007 Aug;23(4):203-10.

12. Tronstad L, Trope M, Bank M, Barnett F. Surgical access for endodontic treatment of intruded teeth. Endod Dent Traumatol. 1986 Apr;2(2):75-8.

13. Panzarini SR, Pedrini D, Poi WR, Sonoda CK, Brandini DA, Castro JCM. Dental trauma involving root fracture and periodontal ligament injury: a 10-year retrospective study. Braz Oral Res. 2008 Jul-Sep;22(3):229-34.

14. Castro MAM, Poi WR, Castro JCM, Panzarini SR, Sonoda CK, Trevisan CL, et al. Crown and crown-root fractures: an evaluation of the treatment plans for management proposed by 154 specialists in restorative dentistry. Dent Traumatol. 2010 Jun;26(3):236-42.

15. Flores MT, Andersson L, Andreasen JO, Bakland LK, Malmgren B, Barnett F, et al. Guidelines for the management of traumatic dental injuries. I. Fractures and luxations of permanent teeth. Dent Traumatol. 2007 Apr;23(2):66-71.

16. Jackson NG, Waterhouse PJ, Maguire A. Management of dental trauma in primary care: a postal survey of general dental practitioners. Br Dent J. 2005 Mar;198(5):293-7. 